\title{
Endovascular stent graft repair with chimney technique of an abdominal aortic aneurysm with concomitant horseshoe kidney
}

\author{
Eşzamanlı at nalı böbreği olan abdominal aort anevrizmasının baca yöntemi ile \\ endovasküler stent greft tamiri
}

Kamil Boyacıoğlu' 1 , Serkan Ketenciler² (D)

Institution where the research was done:

Health Sciences University, Bağcılar Training and Research Hospital, Istanbul, Turkey

Author Affiliations:

'Department of Cardiovascular Surgery, Health Sciences University, Bağcilar Training and Research Hospital, Istanbul, Turkey 2Department of Cardiovascular Surgery, Health Sciences University, Okmeydanı Training and Research Hospital, Istanbul, Turkey

\begin{abstract}
A 68-year-old male patient was referred to our clinic for treatment of an infrarenal abdominal aortic aneurysm. Computed tomography angiography revealed a horseshoe kidney overlying the aneurysm. The patient had an accessory renal artery arising from the anterior aspect of the aneurysm. Endovascular aneurysm repair was performed and the accessory renal artery could be revascularized successfully by chimney technique without any morbidity. Postoperative computed tomography angiography revealed complete exclusion of the aneurysm with no endoleak and a patent chimney graft.
\end{abstract}

Keywords: Accessory renal artery, chimney technique, endovascular aneurysm repair, fenestration, snorkel.

A horseshoe kidney (HSK) is one of the most frequent anatomic variations of the urogenital system which is rarely associated with an abdominal aortic aneurysm (AAA) ${ }^{[1]}$ Conventional open transabdominal or retroperitoneal approaches pose certain challenges for vascular surgeons due to the accessory renal arteries. Endovascular aneurysm repair (EVAR) has been accepted as an alternative method in eligible cases; however, there are some obstacles of maintaining the renal blood flow. ${ }^{[2,3]}$ Herein, we present a chimney endovascular aneurysm repair (ChEVAR) technique to treat an adult patient with an AAA with a concomitant

\section{$\ddot{O} Z$}

Altmış sekiz yaşında erkek hasta infrarenal abdominal aort anevrizmasının tedavisi için kliniğimize sevk edildi. Bilgisayarlı tomografi anjiyografide anevrizmanın üstünde at nalı böbreği izlendi. Hastada anevrizmanın ön tarafından çıkan aksesuar renal arter mevcut idi. Endovasküler anevrizma tamiri yapıldı ve aksesuar renal arter baca tekniği ile morbidite olmadan başarılı bir şekilde revaskülarize edildi. Ameliyat sonrası bilgisayarlı tomografi anjiyografide, kaçak olmaksızın ve baca greft açıklığı ile anevrizmanın tamamen ekarte edildiği görüldü.

Anahtar sözcükler: Aksesuar renal arter, baca tekniği, endovasküler anevrizma tamiri, fenestrasyon, şnorkel.

HSK and accessory renal artery originating from the aneurysmal aorta.

\section{CASE REPORT}

A 68-year-old man was referred to our clinic for the treatment of an infrarenal AAA. His medical history included hypertension, chronic obstructive pulmonary disease, and obesity. Computed tomography angiography (CTA) revealed a HSK overlying $6.5-\mathrm{cm}$ AAA with three renal arteries: $4 \mathrm{~mm}$ left renal artery and $4 \mathrm{~mm}$ right renal artery which supply the superior poles of the HSK and separated from the

Received: September 23, 2019 Accepted: January 09, 2020 Published online: April 22, 2020

Correspondence: Kamil Boyacıoğlu, MD. Sağlık Bilimleri Üniversitesi, Bağcılar Eğitim ve Araştırma Hastanesi, Kalp ve Damar Cerrahisi Kliniği, 34200 Bağcılar, İstanbul, Türkiye. Tel: +90 212 - 4404000 e-mail: kamilboyacioglu@yahoo.com.tr 

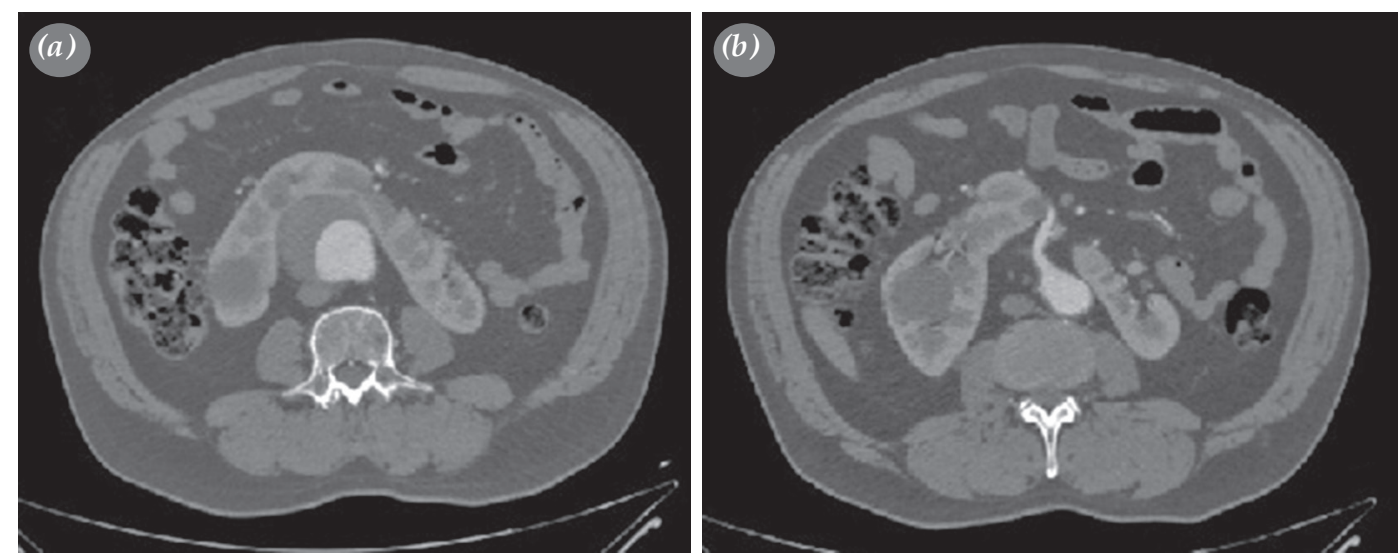

Figure 1. (a) Cross-sectional imaging showing an abdominal aortic aneurysm with horseshoe kidney. (b) A computed tomography angiographic scan showing a large accessory renal artery.

aorta at the level of the superior mesenteric artery and one large accessory renal artery with a length of $5 \mathrm{~cm}$ and $7 \mathrm{~mm}$ in diameter arising from the anterior aspect of the aneurysm which supply the isthmus and inferior poles of the HSK (Figure 1). Between the renal arteries and beginning of the aneurysm, there was a completely normal, long infrarenal neck. The aortic neck length was approximately $6 \mathrm{~cm}$ in length and $28 \mathrm{~mm}$ in diameter (Figure 2). The ChEVAR approach was selected to revascularize the large accessory renal artery. A written informed consent was obtained from the patient.
Firstly, the accessory renal artery was cannulated with a wire via the left brachial artery. A $7 \times 59-\mathrm{mm}$ Atrium Advanta $^{\mathrm{TM}}$ V12 covered stent (Maquet GmbH, Rastatt, Germany) was advanced into the accessory renal artery and left undeployed. Bilateral groin incision was performed. A bifurcated 36 $\times 20 \times 145 \mathrm{~mm}^{3}$ Endurant $^{\mathrm{TM}}$ II (Medtronic Inc., MN, USA) main body was deployed successfully from the left common femoral artery. In this case, we performed $30 \%$ oversizing for the main body. Next, the accessory renal artery chimney stent was deployed and proximal remodeling was done using the kissing balloon technique (Figure 2).
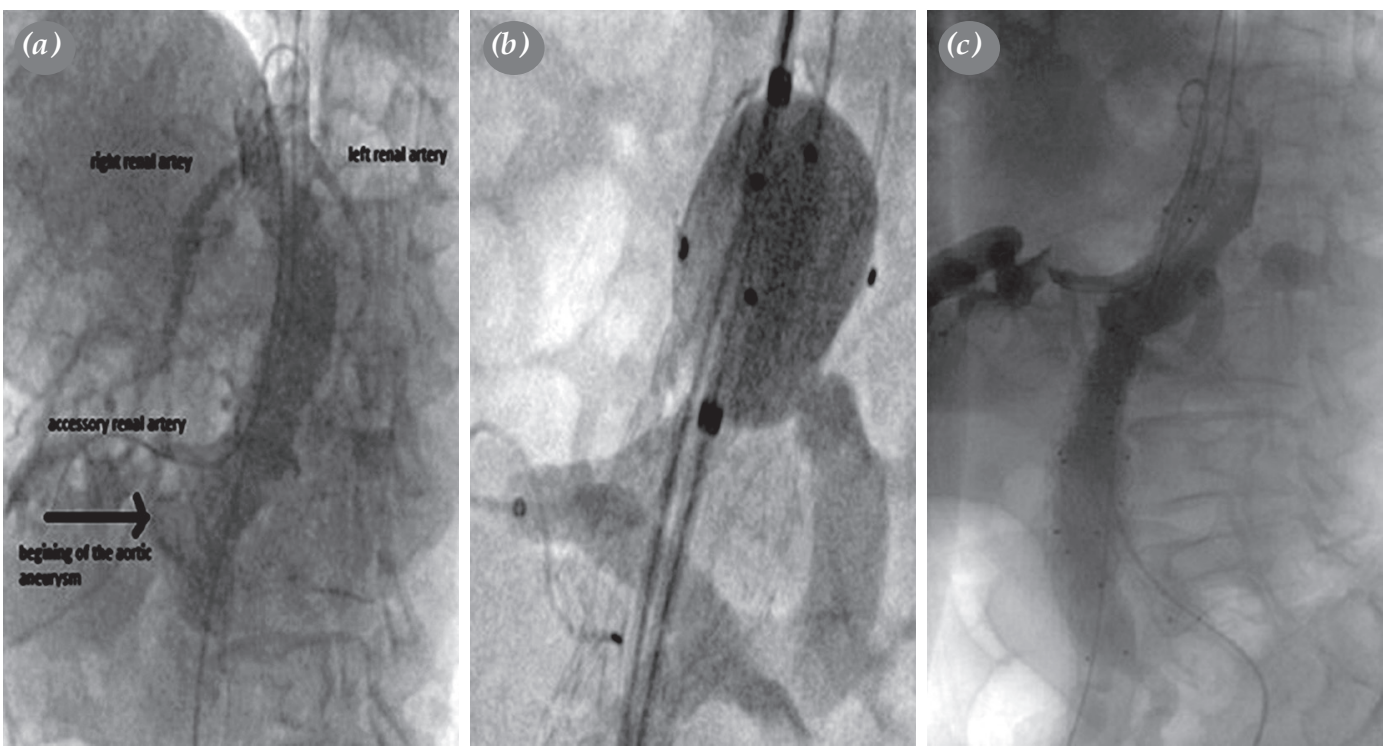

Figure 2. (a) Completion angiogram showing long aortic neck and anatomy of entire renal arteries. (b) A chimney stent deployed in the accessory renal artery and proximal remodeling using kissing balloon technique. (c) Completion angiogram after placement of accessory renal artery chimney stent and endovascular aneurysm repair. 


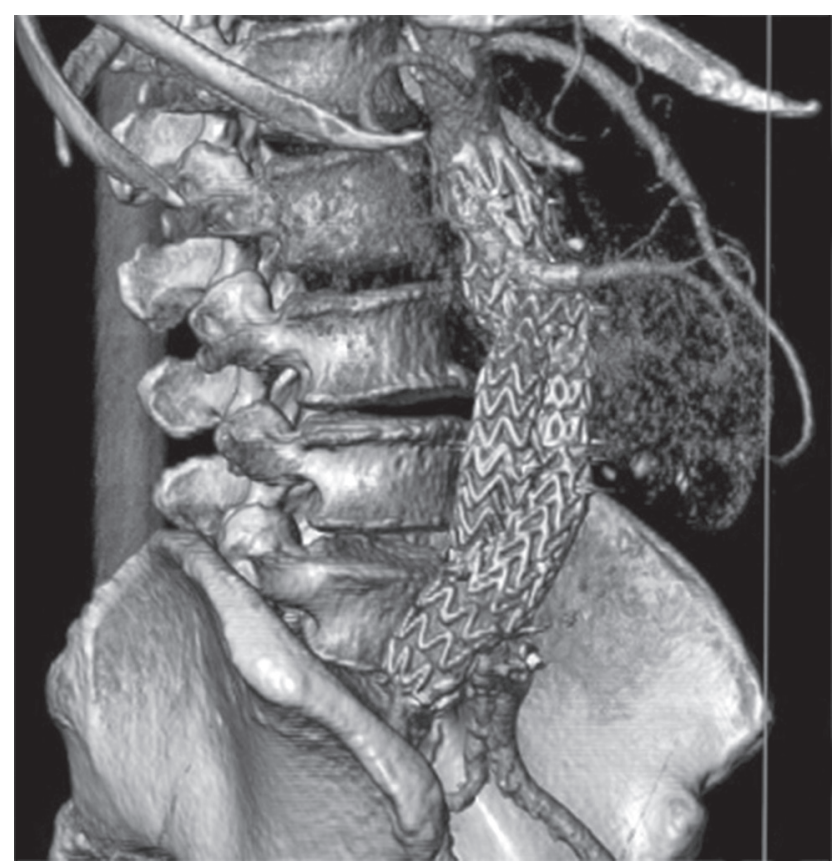

Figure 3. Chimney technique for revascularization of accessory renal artery: Three-dimensional reconstruction of follow-up computed tomography angiography scan showing a widely patent accessory renal artery stent.

The main body was extended $\left(20 \times 20 \times 82 \mathrm{~mm}^{3}\right)$ with Endurant $^{\mathrm{TM}}$ II in the left common iliac artery. Finally, two Endurant ${ }^{\mathrm{TM}}$ II limb extensions $\left(16 \times 24 \times 93 \mathrm{~mm}^{3}\right.$ and $24 \times 24 \times 82 \mathrm{~mm}^{3}$ ) were consecutively deployed into

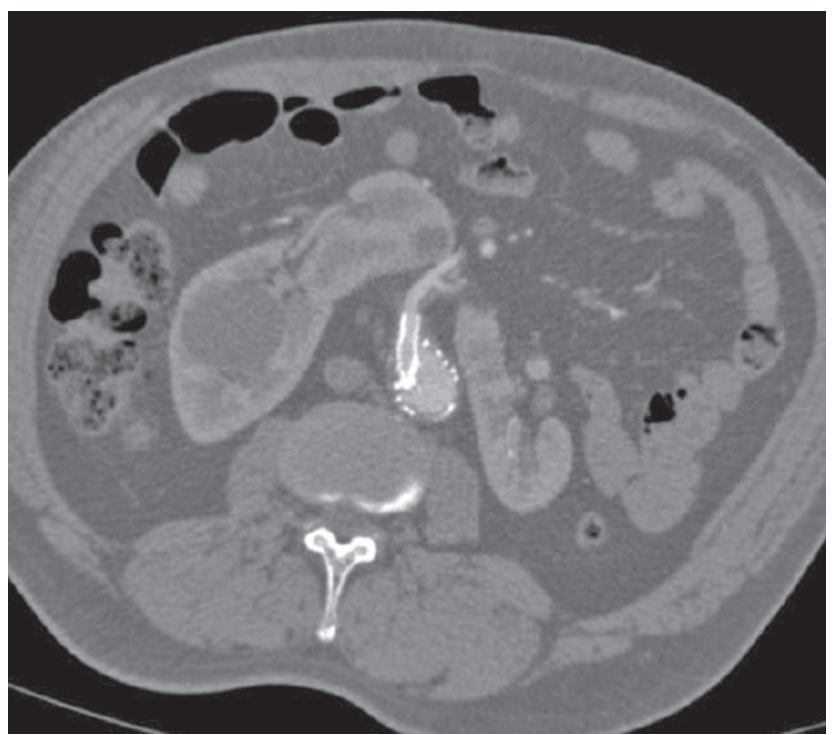

Figure 4. Computed tomography angiography showing a patent accessory renal artery stent and horseshoe kidney.

the right common iliac artery. Extensions on both sides were terminated just proximal to the iliac bifurcation, and there was no extension to the external iliac artery (the right common iliac artery was $21.3 \mathrm{~mm}$ and the left common iliac artery was $21.7 \mathrm{~mm}$ in diameter). A completion angiogram showed patent renal arteries, chimney stent graft of the accessory renal artery, and no apparent endoleak (Figure 2).
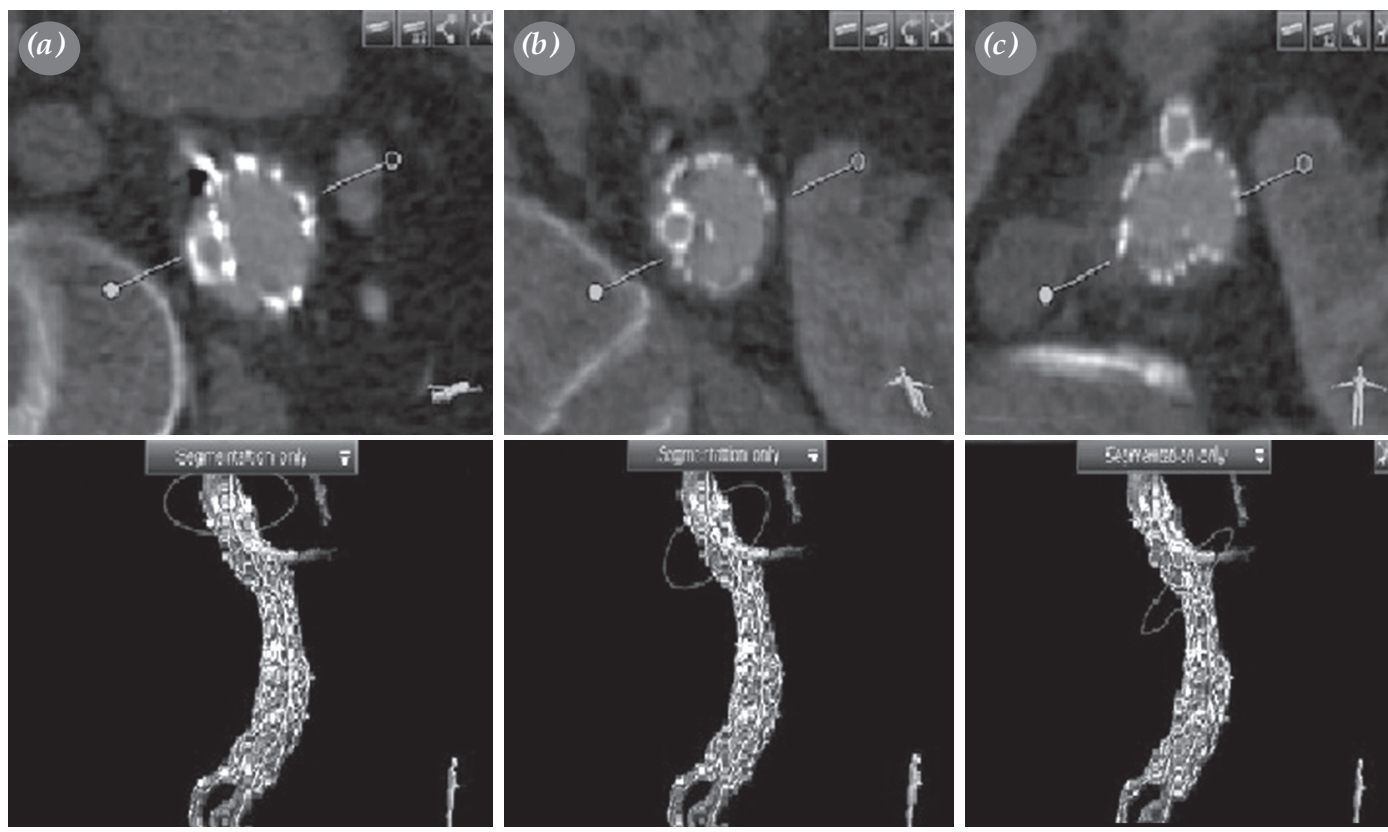

Figure 5. (a-c) Computed tomography angiography and its reconstruction showing the interaction between accessory renal artery chimney stent and proximal endovascular aneurysm repair fixation at different levels. 
The patient's postoperative course was uneventful and he was discharged on postoperative Day 2 with no renal impairment. A postoperative CTA after one year revealed complete exclusion of the AAA with no endoleak and a patent chimney graft (Figures 3-5).

\section{DISCUSSION}

The coexistence of HSK and AAA occurs in only $0.12 \%$ of patients undergoing aneurysm repair. ${ }^{[1]}$ Although the HSK usually provides the patient with normal renal function, this pathology has certain surgical challenges due to the management of the renal isthmus and accessory renal vasculature. A study showed that the mean number of renal arteries was 3.2 (range, 2 to 16) in patients with both HSK and AAA. ${ }^{[4]}$ Thus, in some patients with AAA, the accessory renal arteries may originate from any aspect of the aneurysmal aorta as in our case. In these patients, adequate renal perfusion cannot be achieved or can be more difficult during the treatment of AAAs.

Benefits of using EVAR to exclude an AAA with HSK include the lower morbidity rates. ${ }^{[3]}$ In patients with HSK, accessory renal arteries often create the obstacles for proximal seal zone. Various techniques including chimneys/snorkels, fenestration/branching, and hybrid repairs can be applied to overcome these challenges and maintain the renal circulation. Accessory renal artery sacrifice is another option to achieve an adequate proximal seal zone, but is not ideal, as renal ischemia and/or endoleak may occur. Aquino et al. $^{[3]}$ documented successful sacrifice of 26 accessory renal arteries to facilitate endovascular AAA repair in 24 patients. Five patients had segmental renal infarction associated without renal failure development, and one patient had a transient elevation in serum creatinine level. Although the maintaining entire renal perfusion should be the main goal to prevent renal comorbidities, it seems to be safe to sacrifice the small caliber $(\leq 3 \mathrm{~mm})$ accessory renal arteries. ${ }^{[3,5]}$ Larger accessory renal arteries should be preserved to minimize the risk for renal impairment. In our case, there was a large accessory renal artery arising from the anterior aspect of the aneurysm and we planned revascularization of this artery to avoid renal insufficiency. The ChEVAR was considered as the most appropriate option for our patient. We provided revascularization of the accessory renal artery using the ChEVAR technique without any morbidity. The chimney technique is used to treat complex aortic pathologies such as juxta/suprarenal aortic aneurysm, aortic arch aneurysm and type 1 endoleaks after prior endovascular aortic aneurysm repair. However, in an urgent setting, the chimney technique may be preferred as it requires time for manufacture of fenestrated or branched grafts. Type 1 gutter endoleak after the chimney procedure may occur in 11 to $13 \%$ of cases. ${ }^{[6]}$ The degree of oversizing may reduce the risk for type 1 endoleak. Oversizing of $30 \%$ of the Endurant ${ }^{\mathrm{TM}}$ stent graft is associated with a significant lower incidence of type $1 \mathrm{~A}$ endoleaks.$^{[7]}$ In our case, we performed $30 \%$ oversizing and encountered no type 1 endoleak. The ideal stent combination for the ChEVAR still remains controversial; however, a recent study has shown that use of nitinol/polyester stent graft devices with a balloon-expandable covered stent during the ChEVAR is associated with improved survival ${ }^{[8]}$ This technique has a low early morbidity and mortality rate with high long-term patency rates. ${ }^{[9]}$

In conclusion, the chimney endovascular aneurysm repair should be considered as a feasible option for exclusion of abdominal aortic aneurysms in patients with horseshoe kidney and large accessory renal arteries to maintain the renal circulation entirely. Although this technique can be performed safely and effectively in these patients, a thorough evaluation of the horseshoe kidney and its vasculature is essential before the intervention.

\section{Declaration of conflicting interests}

The authors declared no conflicts of interest with respect to the authorship and/or publication of this article.

\section{Funding}

The authors received no financial support for the research and/or authorship of this article.

\section{REFERENCES}

1. Sachsamanis G, Charisis N, Maltezos K, Galyfos G, Papapetrou A, Tsiliggiris V, et al. Management and therapeutic options for abdominal aortic aneurysm coexistent with horseshoe kidney. J Vasc Surg 2019;69:1257-67.

2. Rey J, Golpanian S, Yang JK, Moreno E, Velazquez OC, Goldstein LJ, et al. Extra-anatomic endovascular repair of an abdominal aortic aneurysm with a horseshoe kidney supplied by the aneurysmal aorta. Ann Vasc Surg 2015;29:1021.

3. Aquino RV, Rhee RY, Muluk SC, Tzeng EY, Carrol NM, Makaroun MS. Exclusion of accessory renal arteries during endovascular repair of abdominal aortic aneurysms. J Vasc Surg 2001;34:878-84.

4. Stroosma OB, Kootstra G, Schurink GW. Management of aortic aneurysm in the presence of a horseshoe kidney. Br J Surg 2001;88:500-9.

5. Kaplan DB, Kwon CC, Marin ML, Hollier LH. Endovascular repair of abdominal aortic aneurysms in patients with congenital renal vascular anomalies. J Vasc Surg 1999;30:407-15. 
6. Lindblad B, Bin Jabr A, Holst J, Malina M. Chimney grafts in aortic stent grafting: hazardous or useful technique? Systematic review of current data. Eur J Vasc Endovasc Surg 2015;50:722-31.

7. Donas KP, Usai MV, Taneva GT, Criado FJ, Torsello GB, Kubilis $\mathrm{P}$, et al. Impact of aortic stent-graft oversizing on outcomes of the chimney endovascular technique based on a new analysis of the PERICLES Registry. Vascular 2019;27:175-80.
8. Scali ST, Beck AW, Torsello G, Lachat M, Kubilis P, Veith FJ, et al. Identification of optimal device combinations for the chimney endovascular aneurysm repair technique within the PERICLES registry. J Vasc Surg 2018;68:24-35.

9. Usai MV, Torsello G, Donas KP. Current evidence regarding chimney graft occlusions in the endovascular treatment of pararenal aortic pathologies: a systematic review with pooled data analysis. J Endovasc Ther 2015;22:396-400. 